\title{
Correction to: Modulation of lipolysis and glycolysis pathways in cancer stem cells changed multipotentiality and differentiation capacity toward endothelial lineage
}

Ayda Pouyafar ${ }^{1}$, Milad Zadi Heydarabad ${ }^{1}$, Jalal Abdolalizadeh ${ }^{2}$, Reza Rahbarghazi ${ }^{2,3^{*}+}$ (D) and Mehdi Talebi ${ }^{2^{*+}}$

\section{Correction to: Cell Biosci (2019) 9:30}

https://doi.org/10.1186/s13578-019-0293-z

In the publication of this article [1], there is an error in one of the contributing author names.

The error: 'Jalal Abdolali Zade'

Should instead read: 'Jalal Abdolalizadeh'

This has now been updated in the original article [1].

\section{Author details}

${ }^{1}$ Stem Cell Research Center, Tabriz University of Medical Sciences, Imam Reza St., Daneshgah St., Tabriz 5166614756, Iran. ${ }^{2}$ Drug Applied Research Center, Tabriz University of Medical Sciences, Tabriz, Iran. ${ }^{3}$ Department of Applied Cell Sciences, Faculty of Advanced Medical Sciences, Tabriz University of Medical Sciences, Tabriz, Iran.

The original article can be found online at https://doi.org/10.1186/s1357 8-019-0293-z.

\author{
Received: 10 April 2019 Accepted: 10 April 2019
}

Reference

1. Pouyafar A, Heydarabad MZ, Abdolalizadeh J, Rahbarghazi R, Talebi M. Modulation of lipolysis and glycolysis pathways in cancer stem cells changed multipotentiality and differentiation capacity toward endothelial lineage. Cell Biosci. 2019;9:30. https://doi.org/10.1186/s1357 8-019-0293-z.

\section{Publisher's Note}

Springer Nature remains neutral with regard to jurisdictional claims in published maps and institutional affiliations.

\footnotetext{
*Correspondence: rahbarghazir@tbzmed.ac.ir;

rezarahbardvm@gmail.com; m.talebi.tbzmed@gmail.com

${ }^{+}$Reza Rahbarghazi and Mehdi Talebi contributed equally to this work

${ }^{2}$ Drug Applied Research Center, Tabriz University of Medical Sciences,

Tabriz, Iran

Full list of author information is available at the end of the article
} 